\title{
Reclassification of the Sporobolomyces roseus and Sporidiobolus pararoseus complexes, with the description of Sporobolomyces phaffii
} sp. nov.

1 Systematic Mycology and Lichenology Laboratory, Institute of Microbiology, Chinese Academy of Sciences, Beijing 100080, China

2 Japan Collection of Microorganisms, RIKEN (The Institute of Physical and Chemical Research), Wako, Saitama, 351-0198, Japan

3 Yeast Division, Centraalbureau voor Schimmelcultures, Uppsalalaan 8, $3594 \mathrm{CT}$ Utrecht, The Netherlands

${ }^{4}$ Yothi Research Unit, National Center for Genetic Engineering and Biotechnology (BIOTEC) National Science and Technology Development Agency (NSTDA), 73/1 Rama VI Road, Bangkok 10400, Thailand

\author{
Feng-Yan Bai, ${ }^{1}$ Jian-Hua Zhao, ${ }^{1}$ Masako Takashima, ${ }^{2}$ Jian-Hua Jia, ${ }^{1}$ \\ Teun Boekhout ${ }^{3}$ and Takashi Nakase Na, $^{2,4}$
}

\begin{abstract}
Author for correspondence: Feng-Yan Bai. Tel: +86106255 5692. Fax: +861062560912. e-mail: baify@sun.im.ac.cn
\end{abstract}

\begin{abstract}
More than $\mathbf{5 0}$ ballistoconidium-forming yeast strains, isolated from plant leaves collected in Yunnan, China, were identified as Sporobolomyces roseus Kluyver \& van Niel by conventional methods. However, comparison of the internal transcribed spacer (ITS) region and 26S rDNA D1/D2 domain sequences indicated that these strains represented more than one species. Type or authentic strains of the synonyms of Sporobolomyces roseus and the closely related species Sporidiobolus pararoseus Fell \& Tallman were employed in the rDNA sequence comparison. Sporobolomyces boleticola Ramírez, Sporobolomyces pollaccii Verona \& Ciferri, Sporobolomyces roseus var. madurae Janke and Torulopsis somala Verona were confirmed to be conspecific with Sporobolomyces roseus. Another synonym of this species, Sporobolomyces salmoneus Derx, was located together with Sporobolomyces marcillae Santa Maria in a separate clade. Two synonyms of Sporidiobolus pararoseus, Sporobolomyces carnicolor Yamasaki \& Fujii (nom. inval.) and Sporobolomyces japonicus lizuka \& Goto, were revealed to represent two distinct species. The name Sporobolomyces carnicolor is validated, with strain CBS $\mathbf{4 2 1 5}^{\top}$ as the type strain. A novel species represented by five of the selected Yunnan strains was confirmed, for which the name Sporobolomyces phaffii sp. nov. is proposed (type strain CH $2.052^{\top}=$ AS $2.2137^{\top}=J C M 11491^{\top}=$ CBS 9129'). This study also indicates that yeast species with similar ITS sequences may have quite different $D 1 / D 2$ sequences.
\end{abstract}

Keywords: Sporobolomyces phaffii sp. nov., Sporobolomyces roseus, Sporidiobolus pararoseus, Sporobolomyces carnicolor, Sporobolomyces japonicus

\section{INTRODUCTION}

Sporobolomyces roseus Kluyver \& van Niel is a common ballistoconidium-forming yeast species and occurs in many different habitats, but most frequently in the phyllosphere (Derx, 1930; Tubaki, 1953; Last, 1955; Nakase, 2000). According to the recent taxo-

Published online ahead of print on 27 May 2002 as DOI 10.1099/ ijs.0.02297-0.

Abbreviation: ITS, internal transcribed spacer.

The GenBank accession numbers for the sequences determined in this study are AY069991-AY070006 (ITS region) and AY070007-AY070018 (26S rDNA D1/D2 domain) as indicated in Fig. 1. nomic system of basidiomycetous yeasts (Boekhout \& Nakase, 1998), more than 50 ballistoconidiumforming yeast strains isolated from various wilting leaves collected in Yunnan, China, in 1996 were identified as Sporobolomyces roseus by conventional methods. However, these strains varied to different degrees in carbon and nitrogen compound assimilation patterns. Comparison of the internal transcribed spacer (ITS) region and 26S rDNA D1/D2 domain sequences of representatives of these strains showed that more than one species existed among them. Therefore, the species circumscription of Sporobolomyces roseus should be redefined.

The authentic strains of two synonyms of Sporobolo- 
myces roseus, Sporobolomyces ruberrimus Yamasaki \& Fujii var. ruberrimus (CBS 7500) and Sporobolomyces ruberrimus var. albus Yamasaki \& Fujii (CBS 7253, CBS 7501), have been shown to represent a distinct species by D1/D2 domain sequence analysis (Fell et al., 2000). The type or authentic strains of the remaining synonyms of Sporobolomyces roseus were employed in the present study, when available from culture collections. Since Sporobolomyces roseus is phenotypically similar and phylogenetically closely related to Sporobolomyces shibatanus (Okunuki) Verona \& Ciferri, the anamorph of Sporidiobolus pararoseus Fell \& Tallman (Boekhout, 1991; Boekhout \& Nakase, 1998; Hamamoto \& Nakase, 2000), the type strains of the synonyms of the latter species were also included. The taxonomic status of these taxa was clarified by ITS region and D1/D2 domain sequence analysis. The taxonomic positions of representative Yunnan strains were determined and a hitherto undescribed yeast species was found among them. We describe the latter as Sporobolomyces phaffii sp. nov., in honour of the late Herman J. Phaff.

\section{METHODS}

Yeast strains and characterization. The yeast strains examined are listed in Table 1. The strains from Yunnan were isolated by the improved ballistoconidium-fall method (Nakase \& Takashima, 1993). Type and authentic strains were obtained from the Centraalbureau voor Schimmelcultures (CBS), The Netherlands, and the Japan Collection of Microorganisms (JCM), Japan.

Most of the morphological, physiological and biochemical characteristics were examined according to standard methods commonly employed in yeast taxonomy (Yarrow, 1998). Assimilation of nitrogen compounds was investigated on solid media with starved inocula as described by Nakase \& Suzuki (1986). Vitamin requirement tests were performed according to Komagata \& Nakase (1967).

Extraction, purification and identification of ubiquinones were carried out according to Nakase \& Suzuki (1986). Xylose in the cell hydrolysate was analysed by HPLC as described by Suzuki \& Nakase (1988).

ITS region and 26S rDNA D1/D2 domain sequencing. Nuclear DNA was extracted using the method of Makimura et al. (1994). The DNA fragment covering the ITS region and 26S rDNA D1/D2 domain was amplified with the primers ITS1 (5'-GTCGTAACAAGGTTTCCGTAGGTG-3') and NL4 (5'-GGTCCGTGTTTCAAGACGG-3'). PCR was performed for 36 cycles of denaturation at $94{ }^{\circ} \mathrm{C}$ for $1 \mathrm{~min}$, annealing at $52{ }^{\circ} \mathrm{C}$ for $1 \mathrm{~min}$ and extension at $72{ }^{\circ} \mathrm{C}$ for $1.5 \mathrm{~min}$. Cycle sequencing was performed with the forward primers ITS1 and NL1 (5'-GCATATCAATAAGCGGAGGAAAAG-3') and the reverse primers ITS4 (5'-TCCTCCGCTTATTGATATGC-3') and NL4 using the ABI

Table 1. Yeast strains employed

\begin{tabular}{|c|c|}
\hline Strain & Source/notes \\
\hline \multicolumn{2}{|l|}{ Sporidiobolus pararoseus } \\
\hline CBS $491^{\mathrm{T}}$ & Soil \\
\hline CBS 484 & Type of Sporobolomyces pararoseus \\
\hline Sporobolomyces blumeae JCM $10212^{\mathrm{T}}$ & Blumea sp. \\
\hline Sporobolomyces carnicolor CBS $4215^{\mathrm{T}}$ & Unknown \\
\hline Sporobolomyces japonicus CBS $5744^{\mathrm{T}}$ & Oil brine \\
\hline Sporobolomyces marcillae CBS $4217^{\mathrm{T}}$ & Air \\
\hline \multicolumn{2}{|l|}{ Sporobolomyces phaffii sp. nov. } \\
\hline $\mathrm{CH} 2.049$ & Wilting leaf of Ehretia corylifolia \\
\hline $\mathrm{CH} 2.052^{\mathrm{T}}$ & Wilting leaf of Nerium indicum \\
\hline CH 2.083 & Wilting leaf of Oxytenanthera sp. \\
\hline CH 2.091 & Wilting leaf of Eriobotrya japonica \\
\hline CH 2.304 & Wilting leaf of Oryza sativa \\
\hline \multicolumn{2}{|l|}{ Sporobolomyces roseus } \\
\hline CBS 485 & Type of Sporobolomyces pollaccii \\
\hline CBS $486^{\mathrm{T}}$ & Type of Sporobolomyces roseus \\
\hline CBS 993 & Type of Torulopsis somala \\
\hline CBS 2646 & Type of Sporobolomyces roseus var. madurae \\
\hline CBS 2840 & Authentic strain of Sporobolomyces boleticola \\
\hline CBS 2841 & Authentic strain of Sporobolomyces boleticola \\
\hline CH 2.053 & Wilting leaf of Nerium indicum \\
\hline $\mathrm{CH} 2.116$ & Wilting leaf of Sapindus delavayi \\
\hline CH 2.332 & Wilting leaf of Nicotiana tabacum \\
\hline Sporobolomyces ruberrimus CBS $7500^{\mathrm{T}}$ & Air \\
\hline Sporobolomyces salmoneus CBS $488^{\mathrm{T}}$ & Etiolated grass \\
\hline Sporobolomyces sp. CH 2.500 & Wilting leaf of Parthenocissus sp. \\
\hline
\end{tabular}


BigDye cycle sequencing kit. Electrophoresis was done on an ABI PRISM 377 DNA sequencer.

Molecular phylogenetic analysis. The sequences of the ITS regions or $26 \mathrm{~S}$ rDNA D1/D2 domains of the strains determined in this study and the reference sequences were aligned with the program CLUSTAL X (Thompson et al., 1997) and adjusted manually. Reference sequences were obtained from DDBJ/EMBL/GenBank, where they had been deposited by other authors (Fell et al., 2000; Takashima \& Nakase, 2000). Phylogenetic trees were constructed from the evolutionary distance data calculated from Kimura's twoparameter model (Kimura, 1980) using the neighbourjoining method (Saitou \& Nei, 1987). Bootstrap analyses (Felsenstein, 1985) were performed on 1000 random resamplings.

\section{RESULTS AND DISCUSSION}

\section{Taxonomic status of the synonyms of Sporobolomyces roseus and Sporidiobolus pararoseus}

Boekhout (1991) and Boekhout \& Nakase (1998) listed 15 taxonomic synonyms under Sporobolomyces roseus. The type or authentic strains are available from culture collections for only eight of them. The sequences of the ITS regions and D1/D2 domains of these strains were determined in the present study, except for the D1/D2 sequence of the type strain of Sporobolomyces ruberrimus, which had been determined by Fell et al. (2000).

Among the taxonomic synonyms of Sporidiobolus pararoseus listed by Boekhout (1991) and Boekhout \& Nakase (1998), Sporobolomyces pararoseus Olson \& Hammer (CBS 484 ${ }^{\mathrm{T}}$, $\mathrm{mt} \mathrm{A} 1$ ) and Sporobolomyces ruber Yamasaki \& Fujii (nom. inval., CBS 4216, mt A2) have been confirmed to be conspecific with the former by mating compatibility and D1/D2 sequencing (Boekhout, 1991; Statzell-Tallman \& Fell, 1998; Fell et al., 2000). Sporobolomyces marcillae Santa Maria was shown to be a distinct species by D1/D2 sequencing (Fell et al., 2000). The type or authentic strains of the remaining two synonyms of Sporidiobolus pararoseus, Sporobolomyces carnicolor Yamasaki \& Fujii (nom. inval.) and Sporobolomyces japonicus Iizuka \& Goto, were used in this study for ITS and D1/D2 sequencing. In addition, the ITS sequence of the type strain of Sporobolomyces marcillae was determined.

The relationships among the taxa studied are depicted by the phylogenetic trees drawn from the sequences of the ITS region (Fig. 1a) and the D1/D2 domain (Fig. 1b). Sporidiobolus johnsonii and Sporidiobolus salmonicolor were used as outgroups. The recently described species Sporobolomyces blumeae Takashima \& Nakase (2000) formed a basal branch in both trees. The other taxa clustered around Sporobolomyces roseus and Sporidiobolus pararoseus. In the ITS tree (Fig. 1a), both clades were supported strongly (99-100\%) by bootstrap analysis. In the D1/D2 tree (Fig. 1b), the Sporobolomyces roseus clade was strongly supported (bootstrap value 100\%), but the Sporidiobolus pararoseus clade was not (bootstrap value $<50 \%$ ).

Among the synonyms of Sporobolomyces roseus, Sporobolomyces boleticola Ramírez, Sporobolomyces pollaccii Verona \& Ciferri, Sporobolomyces roseus var. madurae Janke and Torulopsis somala Verona were confirmed to be conspecific with Sporobolomyces roseus, because they have ITS and D1/D2 sequences that are identical or very similar (only one nucleotide substitution) to those of the type strain of Sporobolomyces roseus.

Sporobolomyces salmoneus Derx, a synonym of Sporobolomyces roseus, was clearly separated from the Sporobolomyces roseus clade in both trees, and clustered together with Sporobolomyces marcillae in the Sporidiobolus pararoseus clade. The type strains of Sporobolomyces salmoneus and Sporobolomyces marcillae have identical D1/D2 sequences and differ by only $1 \mathrm{nt}$ in their ITS regions.

Two synonyms of Sporidiobolus pararoseus, Sporobolomyces carnicolor and Sporobolomyces japonicus, respectively differed from the type strain by 19-24 and 7-8 nt in the ITS region and D1/D2 domain. They also differed from one another remarkably (Fig. 1). Sporobolomyces carnicolor and Sporobolomyces japonicus should therefore be reinstalled as two distinct species. Sporobolomyces carnicolor was proposed by Yamasaki \& Fujii (1950) without a Latin description or type designation, and therefore needs to be validated.

\section{Taxonomic status of the Sporobolomyces roseus strains from Yunnan}

A total of 670 yeast strains were isolated from 43 wilting leaf samples collected in Yunnan, China, in 1996 using the improved ballistoconidium-fall method (Nakase \& Takashima, 1993). Approximately 100 ballistoconidium-forming yeast strains were initially selected for phenotypic characterization. Of them, a total of 55 strains were identified as Sporobolomyces roseus according to Boekhout (1991) and Boekhout \& Nakase (1998). Of nine representative strains (Table 1) selected for ITS sequencing, strains $\mathrm{CH} 2.053, \mathrm{CH}$ 2.116 and $\mathrm{CH} 2.332$ were confirmed to belong to Sporobolomyces roseus (Fig. 1a). The sequence of strain $\mathrm{CH} 2.500$ differed from that of the type by $5 \mathrm{nt}$ $(1.4 \%)$.

The other five strains, $\mathrm{CH}$ 2.049, CH 2.052, CH 2.083, CH 2.091 and $\mathrm{CH}$ 2.304, had identical ITS sequences and the sequence differed from that of the type strain of Sporobolomyces ruberrimus by $3 \mathrm{nt}(1 \cdot 0 \%)$. Previous studies on basidiomycetous yeasts have indicated that conspecific strains usually have less than $1 \%$ nucleotide divergence in the ITS1 and ITS2 regions overall (Sugita et al., 1999a, b; Takashima \& Nakase, 2000). However, Bai et al. (2001a, b) found that conspecific strains might have up to 5-7 nt differences (approx. 2\%) in the ITS regions. Therefore, the taxonomic relationships of these five strains with 

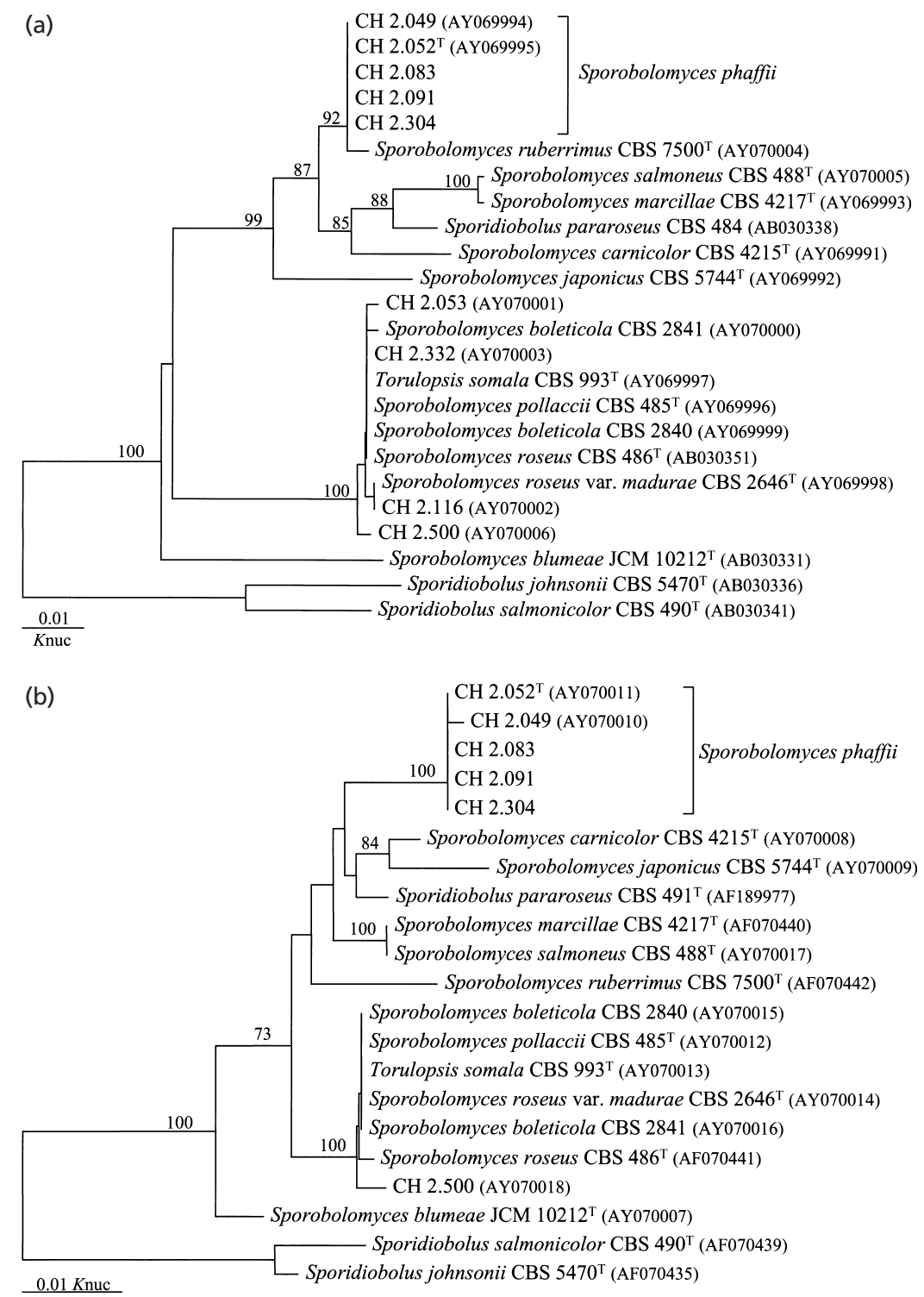

Fig. 1. Phylogenetic trees drawn from neighbour-joining analysis based on sequences of (a) the ITS region (including 5.85 rDNA) and (b) the D1/D2 domain, depicting the relationships of taxa in the Sporobolomyces roseus and Sporidiobolus pararoseus complexes, as well as the novel isolates from Yunnan, China. Bootstrap percentages over $50 \%$ from 1000 bootstrap replicates are shown.

Sporobolomyces ruberrimus and that of strain $\mathrm{CH}$ 2.500 with Sporobolomyces roseus were examined further by D1/D2 sequencing.

Strains CH 2.052, CH 2.083, CH 2.091 and CH 2.304 had identical D1/D2 sequences and differed from $\mathrm{CH}$ 2.049 by only $1 \mathrm{nt}$. They differed from Sporobolomyces ruberrimus in as many as $18-19 \mathrm{nt}(3.0 \%)$ in the D1/D2 domain (Fig. 1b). These results indicate that these strains represent a distinct species, for which the name Sporobolomyces phaffii sp. nov. is proposed.

Strain CH 2.500 differed from the type strain of Sporobolomyces roseus by $3 \mathrm{nt}$ in the D1/D2 domain, suggesting that this strain probably represents a distinct species. A definite taxonomic decision for strain $\mathrm{CH} 2.500$ should be supported by additional data, for example, DNA-DNA reassociation, and perhaps by the identification of additional strains.

\section{The significance of phenotypic and phylogenetic comparison}

The novel species Sporobolomyces phaffii is indistinguishable from Sporobolomyces roseus by conventional characterization. The three species Sporobolomyces carnicolor, Sporobolomyces japonicus and Sporidiobolus pararoseus also have almost identical phenotypes. Sporobolomyces roseus and Sporobolomyces phaffii can be differentiated from the latter three species in their ability to assimilate nitrate and nitrite. Though the type strains of Sporobolomyces salmoneus and Sporobolomyces marcillae have identical D1/D2 sequences and very similar ITS sequences, their nitrogen assimilation patterns are completely different. Sporobolomyces salmoneus can utilize nitrate, nitrite and ethylamine hydrochloride as sole sources of nitrogen, whereas Sporobolomyces marcillae can not. This explains why the former was previously regarded 
as a synonym of Sporobolomyces roseus and the latter a synonym of Sporidiobolus pararoseus (Boekhout, 1991). The taxonomic relationship between Sporobolomyces salmoneus and Sporobolomyces marcillae should be studied further.

The relationships among the taxa in the Sporidiobolus pararoseus complex revealed by the ITS sequences are discordant with those revealed by the D1/D2 sequence data, especially for the relationship between Sporobolomyces phaffii sp. nov. and Sporobolomyces ruberrimus (Fig. 1). Analysis of $18 \mathrm{~S}$ rDNA sequences may be helpful to confirm the phylogenetic relationships among these species. Fell et al. (2000) found that some basidiomycetous yeast species with identical or similar D1/D2 sequences could be separated by ITS sequence data. On the other hand, the present study indicates that species with similar ITS sequences may have quite different D1/D2 sequence data.

\section{Latin diagnosis of Sporobolomyces carnicolor Yamasaki \& Fujii ex Bai \& Boekhout}

In $\mathrm{YM}$ liquido post dies 3 ad $25^{\circ} \mathrm{C}$, cellulae vegetativae ovoideae, ellipsoideae vel elongatae, 2.5-6.2 $\times 3 \cdot 5-$ $17 \mu \mathrm{m}$, singulae, binae vel aggregatae. Post unum mensem ad $20^{\circ} \mathrm{C}$, annulus, pelliculum et sedimentum formantur. In agaro YM post unum mensem ad $20^{\circ} \mathrm{C}$, cultura rubro-aurantiaca, rugosa, margine erosa. Mycelium et pseudomycelium non formantur. Ballistosporae ovoideae vel ellipsoideae, 2.5-3.7 ×6 2-10.2 $\mu \mathrm{m}$. Fermentatio nulla. Glucosum, galactosum (lente), Lsorbosum (lente), saccharosum, maltosum, cellobiosum, trehalosum, raffinosum, melezitosum, inulinum (lente), amylum solubile (lente), D-xylosum (lente), D-arabinosum, D-ribosum, ethanolum, glycerolum, ribitolum (lente), D-mannitolum, glucitolum, methyl $\alpha$-D-glucosidum (lente), salicinum, glucono- $\delta$-lactonum, acidum succinicum et acidum citricum assimilantur at non lactosum, melibiosum, L-arabinosum, L-rhamnosum, erithritolum, galactitolum, acidum 2-ketogluconicum, acidum 5-ketogluconicum, acidum DL-lacticum, inositolum, acidum D-glucuronicum nec acidum D-galacturonicum. Ammonium sulfatum, L-lysinum et cadaverinum assimilantur at non kalium nitricum, natrum nitrosum nec ethylaminum. Ad crescentiam vitaminum non necessarium est. Materia amyloidea iodophila non formantur. Urea finditur. Diazonium caeruleum B positivum. Ubiquinonum majus: Q-10. Typus: CBS $4215^{\mathrm{T}}$, depositus in collectione Centraalbureau voor Schimmelcultures, Utrecht, The Netherlands.

\section{Latin diagnosis of Sporobolomyces phaffii Bai, Takashima \& Nakase sp. nov.}

In YM (Difco) liquido post dies 3 ad $25^{\circ} \mathrm{C}$, cellulae vegetativae ovoideae vel ellipsoideae, 2.0-4.0 $\times 4 \cdot 0$ $4.8 \mu \mathrm{m}$, singulae aut binae. Post unum mensem ad $20^{\circ} \mathrm{C}$, annulus, pelliculum et sedimentum formantur. In agaro YM post unum mensem ad $20^{\circ} \mathrm{C}$, cultura rubroaurantiaca, glabra, nitida, et margine glabra. Mycelium et pseudomycelium non formantur. Ballistosporae ovoi- deae vel ellipsoideae, 2.0-2.2 $\times 8 \cdot 0-9 \cdot 0 \mu \mathrm{m}$. Fermentatio nulla. Glucosum, saccharosum, maltosum, cellobiosum, trehalosum, melibiosum, raffinosum, melezitosum, amylum solubile, ethanolum (lente), D-mannitolum (lente), methyl $\alpha$-D-glucosidum, salicinum, glucono- $\delta$-lactonum et acidum succinicum assimilantur at non galactosum (vel exigue et lente), L-sorbosum, lactosum, inulinum, Dxylosum, L-arabinosum, D-arabinosum, D-ribosum, Lrhamnosum, glycerolum, erithritolum, ribitolum, galactitolum, glucitolum (vel exigue et lente), acidum 2ketogluconicum, acidum 5-ketogluconicum, acidum DLlacticum, acidum citricum, inositolum, acidum D-glucuronicum nec acidum D-galacturonicum. Ammonium sulfatum, kalium nitricum, natrum nitrosum assmilantur, ethylaminum (variabile) et $\mathrm{L}$-lysinum (fortasse exigue) assimilantur at non cadaverinum (vel exigue). Ad crescentiam vitaminum non necessarium est. Maxima temperatura crescentiae: $32-33^{\circ} \mathrm{C}$. Materia amyloidea iodophila non formantur. Urea finditur. Diazonium caeruleum B positivum. Ubiquinonum majus: Q-10. Xylosum in cellulis absens.

Typus: Isolatus ex folio Nerii indici Mill., AS 2.2137 (originaliter ut $\mathrm{CH} 2.052^{\mathrm{T}}$ ) depositus in collectione China General Microbiological Culture Collection Center, Academia Sinica, Beijing.

\section{Description of Sporobolomyces phaffii Bai, Takashima \& Nakase sp. nov.}

Sporobolomyces phaffii (phaf'fi.i. N.L. gen. n. phaffii in honour of the late Herman J. Phaff, USA).

In YM broth, after 3 days at $25^{\circ} \mathrm{C}$, the cells are ovoid to ellipsoidal, 2.0-4.0 $\times 4 \cdot 0-8 \cdot 0 \mu \mathrm{m}$ (Fig. 2a). A ring, pellicle and sediment are formed. After 1 month at $17{ }^{\circ} \mathrm{C}$, a ring, pellicle and sediment are present. On YM agar, after 3 days at $25^{\circ} \mathrm{C}$, the streak culture is butyrous, smooth, glistening with orange to orangered colour. After 1 month at $20^{\circ} \mathrm{C}$, the culture is butyrous and becomes mucoid or reticulate in some areas, orange-red, with the margin entire to eroded. Mycelia and pseudomycelia are not formed on Dalmau plate culture on corn meal agar. On corn meal agar, ballistoconidia are formed on short sterigmata, ellipsoidal or ovoid, 2.0-2.2 $\times 8 \cdot 0-9 \cdot 0 \mu \mathrm{m}$ (Fig. 2b). Glucose is not fermented. The following carbon compounds are assimilated: glucose, sucrose, maltose, cellobiose, trehalose, melibiose, raffinose, melezitose, soluble starch, ethanol (delayed), D-mannitol (delayed), methyl $\alpha$-D-glucoside, salicin, glucono- $\delta$ lactone, succinic acid and citric acid. The following are not assimilated: galactose (or weak and delayed), Lsorbose, lactose, inulin, D-xylose, L-arabinose, Darabinose, D-ribose, L-rhamnose, glycerol, erythritol, ribitol, galactitol, glucitol (or weak and delayed), 2ketogluconic acid, 5-ketogluconic acid, DL-lactic acid, citric acid, inositol, D-glucuronic acid and Dgalacturonic acid. $\mathrm{KNO}_{3}, \mathrm{NaNO}_{2}$, ethylamine (variable) and L-lysine (or weak) are utilized as sole sources of nitrogen; cadaverine is not utilized or is utilized weakly. Growth in vitamin-free medium is positive. 


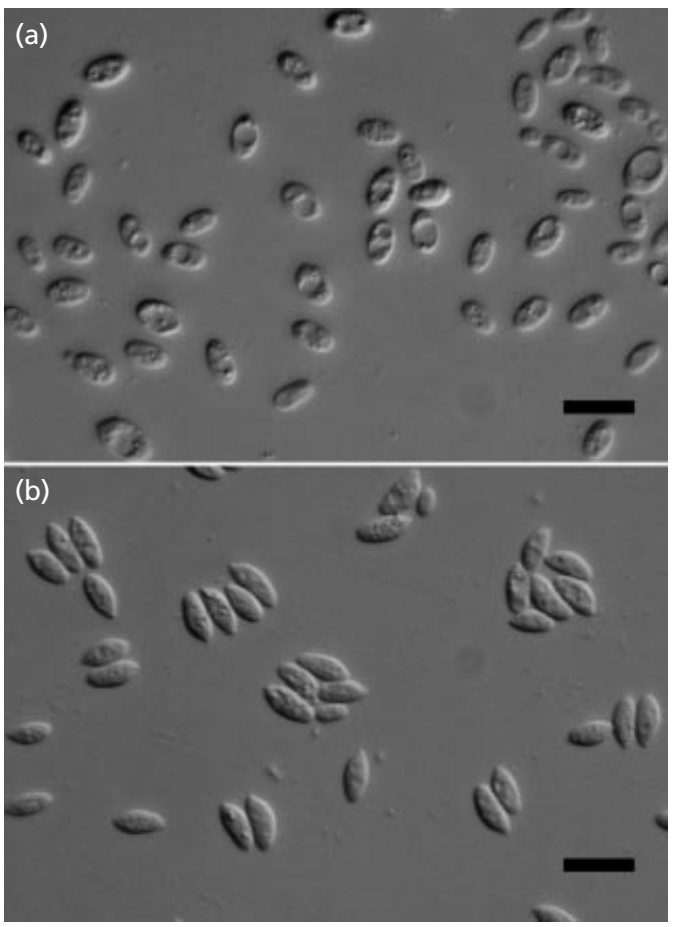

Fig. 2. Sporobolomyces phaffii sp. nov. $\mathrm{CH} 2.052^{\top}$. (a) Vegetative cells grown in YM broth for 5 days at $17^{\circ} \mathrm{C}$. (b) Ballistoconidia produced on corn meal agar after 5 days at $17^{\circ} \mathrm{C}$. Bars, $10 \mu \mathrm{m}$.

Maximum growth temperature is $32-33^{\circ} \mathrm{C}$. Starchlike compounds are not produced. Urease activity is positive. Diazonium blue B reaction is positive. The major ubiquinone is Q-10. Xylose is absent in the whole-cell hydrolysate.

The type strain, strain CH $2.052^{\mathrm{T}}\left(=\mathrm{JCM} 11491^{\mathrm{T}}=\right.$ CBS $9129^{\mathrm{T}}$ ), was isolated in 1996 from a wilting leaf of Nerium indicum Mill. collected in Yunnan, China. This strain has also been deposited in the China General Microbiological Culture Collection Center (CGMCC), Institute of Microbiology, Chinese Academy of Sciences, Beijing, China, as strain AS $2.2137^{\mathrm{T}}$.

\section{ACKNOWLEDGEMENTS}

This study was supported by grants no. 30170002 from the National Natural Science Foundation of China (NSFC) and no. KSCX2-SW-101C from the Chinese Academy of Sciences.

\section{REFERENCES}

Bai, F.-Y., Takashima, M. \& Nakase, T. (2001a). Description of Bullera kunmingensis sp. nov., and clarification of the taxonomic status of Bullera sinensis and its synonyms based on molecular phylogenetic analysis. FEMS Yeast Res 1, 103-109.

Bai, F.-Y., Takashima, M. \& Nakase, T. (2001b). Phylogenetic analysis of strains originally assigned to Bullera variabilis: descriptions of Bullera pseudohuiaensis sp. nov., Bullera komagatae sp. nov. and Bullera pseudoschimicola sp. nov. Int J Syst Evol Microbiol 51, 2177-2187.

Boekhout, T. (1991). A revision of ballistoconidia-forming yeasts and fungi. Stud Mycol 33, 1-194.
Boekhout, T. \& Nakase, T. (1998). Sporobolomyces Kluyver \& van Niel. In The Yeasts, a Taxonomic Study, 4th edn, pp. 828-843. Edited by C. P. Kurtzman \& J. W. Fell. Amsterdam: Elsevier.

Derx, H. G. (1930). Étude sur les Sporobolomycètes. Ann Mycol 28, $1-23$

Fell, J. W., Boekhout, T., Fonseca, A., Scorzetti, G. \& StatzellTallman, A. (2000). Biodiversity and systematics of basidiomycetous yeasts as determined by large-subunit rDNA D1/D2 domain sequence analysis. Int J Syst Evol Microbiol 50, 1351-1371.

Felsenstein, J. (1985). Confidence limits on phylogenies: an approach using the bootstrap. Evolution 39, 783-791.

Hamamoto, M. \& Nakase, T. (2000). Phylogenetic analysis of the ballistoconidium-forming yeast genus Sporobolomyces based on $18 \mathrm{~S}$ rDNA sequences. Int J Syst Evol Microbiol 50, 1373-1380.

Kimura, M. (1980). A simple method for estimating evolutionary rates of base substitutions through comparative studies of nucleotide sequences. J Mol Evol 16, 111-120.

Komagata, K. \& Nakase, T. (1967). Microbiological studies on frozen foods. V. General properties of yeasts isolated from frozen food. Shokuhin Eiseigaku Zasshi 8, 53-57 (in Japanese).

Last, F. T. (1955). Seasonal incidence of Sporobolomyces on cereal leaves. Trans Br Mycol Soc 38, 221-239.

Makimura, K., Murayama, S. Y. \& Yamaguchi, H. (1994). Detection of a wide range of medically important fungi by the polymerase chain reaction. J Med Microbiol 40, 358-364.

Nakase, T. (2000). Expanding world of ballistosporous yeasts: distribution in the phyllosphere, systematics and phylogeny. J Gen Appl Microbiol 46, 189-216.

Nakase, T. \& Suzuki, M. (1986). Bullera megalospora, a new species of yeast forming large ballistospores isolated from dead leaves of Oryza sativa, Miscanthus sinensis, and Sasa sp. in Japan. J Gen Appl Microbiol 32, 225-240

Nakase, T. \& Takashima, M. (1993). A simple procedure for the high frequency isolation of new taxa of ballistosporous yeasts living on the surfaces of plants. RIKEN Review 3, 33-34

Saitou, N. \& Nei, M. (1987). The neighbor-joining method: a new method for reconstructing phylogenetic trees. Mol Biol Evol 4, 406-425.

Statzell-Tallman, A. \& Fell, J. W. (1998). Sporidiobolus Nyland. In The Yeasts, a Taxonomic Study, 4th edn, pp. 693-699. Edited by C. P. Kurtzman \& J. W. Fell. Amsterdam: Elsevier.

Sugita, T., Cañete-Gibas, C. F., Takashima, M. \& Nakase, T. (1999a). Three new species of Bullera isolated from leaves in the Ogasawara Islands. Mycoscience 40, 491-501.

Sugita, T., Nishikawa, A., Ikeda, R. \& Shinoda, T. (1999b). Identification of medically relevant Trichosporon species based on sequences of internal transcribed spacer regions and construction of a database for Trichosporon identification. J Clin Microbiol 37, 1985-1993.

Suzuki, M. \& Nakase, T. (1988). The distribution of xylose in cells of ballistosporous yeasts - application of high performance liquid chromatography without derivatization to the analysis of xylose in whole cell hydrolysates. J Gen Appl Microbiol 34, 95-103.

Takashima, M. \& Nakase, T. (2000). Four new species of the genus Sporobolomyces isolated from leaves in Thailand. Mycoscience 41, 357-369.

Thompson, J. D., Gibson, T. J., Plewniak, F., Jeanmougin, F. \& Higgins, D. G. (1997). The CLUSTAL_X windows interface: flexible strategies for multiple sequence alignment aided by quality analysis tools. Nucleic Acids Res 25, 4876-4882.

Tubaki, K. (1953). Studies on the Sporobolomycetaceae in Japan. III. On Sporobolomyces and Bullera. Nagaoa 3, 12-21.

Yamasaki, I. \& Fujii, H. (1950). Studies on Sporobolomyces red yeasts. Part 7. Classification of the genera Sporobolomyces and Bullera. Bull Agric Chem Soc Japan 24, 11-15 (in Japanese).

Yarrow, D. (1998). Method for the isolation, maintenance and identification of yeasts. In The Yeasts, a Taxonomic Study, 4th edn, pp. 77-100. Edited by C. P. Kurtzman \& J. W. Fell. Amsterdam: Elsevier. 